\title{
Implausibility of an aetiological association between cytomegalovirus and Kaposi's sarcoma shown by four techniques
}

\author{
F VAN DEN BERG, ${ }^{*}$ MARGUERITE SCHIPPER, * M JIWA, $\dagger$ R ROOK, ${ }^{*}$ \\ F VAN DE RIJKE, $\dagger$ B TIGGES*
}

From the ${ }^{*}$ Department of Pathology AMC, University of Amsterdam, and the $†$ Department of Cytochemistry and Cytometry, University of Leiden, The Netherlands

SUMMARY The presence of cytomegalovirus (CMV) was analysed in either lymph node or skin and lung tissue necropsy specimens affected by Kaposi's sarcoma, from 10 patients who had died of AIDS. The different detection techniques used were: (i) immunohistochemical demonstration of CMV immediate early antigen (IEA); (ii) in situ hybridisation with a biotinylated CMV DNA probe; (iii) Southern blot hybridisation of DNA extracted from sequential tissue sections; and (iv) polymerase chain reaction (PCR) with CMV specific primers on the DNA samples. The results of these analyses were compared with the postmortem data on CMV obtained by infectious particle assays and histological examination, especially of adrenal glands of the same patients.

The results of the various detection methods correlated very well, yielding a combined score of six of 10 patients positive for CMV; there did not seem to be any association between the presence of CMV and the occurrence of Kaposi's sarcoma in our patients.

Human cytomegalovirus (CMV) is found in about $90 \%$ of patients with acquired immune deficiency syndrome (AIDS) and is one of the major causes of death of these patients. ${ }^{1}$ CMV infection is most frequently observed in their adrenal glands. ${ }^{12}$ The primary target for CMV in man seems to be epithelial and endothelial cells. ${ }^{2}$

Patients with AIDS often develop Kaposi's sarcoma, malignant tumours of endothelial cell origin ${ }^{3}$ localised in the skin, lymph nodes, lungs and other tissues. It has been suggested that cell transformation induced by CMV may have a role in the development of Kaposi's sarcoma. ${ }^{45}$ More recently DNA hybridisation experiments have indicated that only a small subset of Kaposi's sarcoma samples (15-20\%) contained CMV DNA sequences, which in some cases were derived from occasional productively infected cells.$^{67}$ It was concluded that a causative role for $\mathrm{CMV}$ in Kaposi's sarcoma was questionable.

Accepted for publication 6 October 1988
A few years ago an in vitro DNA amplification technique was described by Saiki and coworkers. ${ }^{8}$ This so-called polymerase chain reaction (PCR) permits a 100000 -fold amplification of specific DNA sequences in a given sample using a heat stable DNA polymerase, ${ }^{9}$ synthetic oligonucleotide primers of specified base sequence, and a regimen of repeated cycles of denaturation, primer annealing, and primer extension. The PCR technique has been successfully used for the amplification of human ${ }^{89}$ and viral ${ }^{1011}$ DNA sequences from complex mixtures with a highly increased sensitivity compared with standard filter hybridisation techniques.

We used four independent techniques including PCR for the detection of CMV "footprints" in tissues of patients with AIDS with variable incidence of Kaposi's sarcoma and compared the results of these analyses with those of histological examination of adrenal glands and virus culture assays. To enable direct comparison of results, sequential cryostat sections were prepared for morphological examination, immunohistochemistry, in situ hybridisation and DNA extraction for Southern blotting and PCR. 


\section{Material and methods}

Tissue affected by Kaposi's sarcoma was sampled at necropsy within six hours of death in 10 patients with AIDS. Both malignant and "normal" looking tissue samples were snap frozen in liquid nitrogen and fixed in $4 \%$ buffered formalin. Routine tissue samples of adrenals, lungs, and trachea were prepared for virus culture techniques. Six patients (cases $1,2,4,5,7,10$ ) died of generalised Kaposi's sarcoma, localised in the lungs, the lymph nodes, the oropharynx and the skin. Two patients (cases 5 and 6) died of generalised CMV infection, and two patients (cases 2 and 8) died of other opportunistic (non-viral) infections (table). CMV inclusion bodies were present in the adrenals of six patients with concomitant necrosis of the adrenal cortex and medulla. In one patient (case 4) the characteristic spotty necrosis was seen without CMV inclusion bodies. Three patients did not have any sign of CMV infection on histological examination. In general, the results of the virus culture confirm these histological findings. In two patients (cases 2 and 6 ) the culture results were unreliable, while three patients had negative viral cultures.

Cryostat sections were cut from snap frozen tissue blocks according to the following scheme: $1 \times 6 \mu \mathrm{m}$ for haematoxylin and eosin stain, $2 \times 6 \mu \mathrm{m}$ for immunohistochemistry, $4 \times 6 \mu \mathrm{m}$ for in situ hybridisation, $20 \times 10 \mu \mathrm{m}$ for DNA extraction (for Southern blotting and PCR) and $1 \times 6 \mu \mathrm{m}$ for haematoxylin and eosin stain.

\section{IMMUNOHISTOCHEMISTRY}

Immunohistochemistry on frozen sections was performed essentially as previously described, ${ }^{12}$ using the mouse monoclonal antibody E13 directed against the immediate early antigen (IEA) of CMV (Biosoft, Paris), except that a three step immunoperoxidase technique with rabbit-anti-mouse-horseradish peroxidase and swine-anti-rabbit-horseradish peroxide was used. $\mathrm{HRP}$ activity was developed with $\mathrm{H}_{2} \mathrm{O}_{2}$ /amino ethyl carbazole according to the method of Graham. ${ }^{13}$ A sequential section of each tissue was incubated with omission of the primary antibody step as a negative control.

\section{IN SITU HYBRIDISATION}

Frozen sections were mounted on gelatin-chrome alum coated slides and fixed in 50\% methanol $/ 50 \%$ acetone at $-20^{\circ} \mathrm{C}$ for 10 minutes. Sections were treated with $0.005 \%$ pepsin (Sigma) in $0.01 \mathrm{~N}$ hydrochloric acid for 30 minutes at $37^{\circ} \mathrm{C}$. After dehydration and drying sections were pre-hybridised in HybMix (= $2 \times \mathrm{SSC}, \mathrm{pH} 7.0,50 \%$ formamide, $250 \mu \mathrm{g} / \mathrm{ml}$ single stranded carrier DNA, $10 \times$ Denhardt's solution, $10 \%$ dextran sulphate, $0 \cdot 5 \%$ tween 20 ) for one hour at $37^{\circ} \mathrm{C}$ and subsequently rinsed in phosphate buffered saline (PBS), $0.5 \%$ Tween 20, dehydrated, and air dried. Biotinylated CMV DNA probe (Janssen Biochimica) (10 ng) or HSV-2 DNA probe (Janssen Biochimica) (10 ng) in $10 \mu \mathrm{l}$ Hybmix was applied to the sections which were covered with a glass coverslip. Probe and target DNA were simultaneously denatured by placing the sections on a $90^{\circ} \mathrm{C}$ hotplate for two minutes. Hybridisation was performed for 18 hours at $37^{\circ} \mathrm{C}$ in a sealed humidified chamber.

Coverslips were removed by submerging the sections in $0.1 \times$ SSC, $0.5 \%$ Tween 20 at $37^{\circ} \mathrm{C}$ and sections were thoroughly rinsed in the same buffer. Hybridised probe sequences were visualised in the sections with a commercially available streptavadin/ poly-alkaline-phosphatase kit (Bethesda Research Laboratories) using nitro-blue-tetrazidium/bromochloroindolyl-phosphate as substrate.

DNA EXTRACTION FROM TISSUE SECTIONS

Cryostat sections were collected in polypropylene

Table Summary of results of CMV detection in necropsy tissue of 10 patients

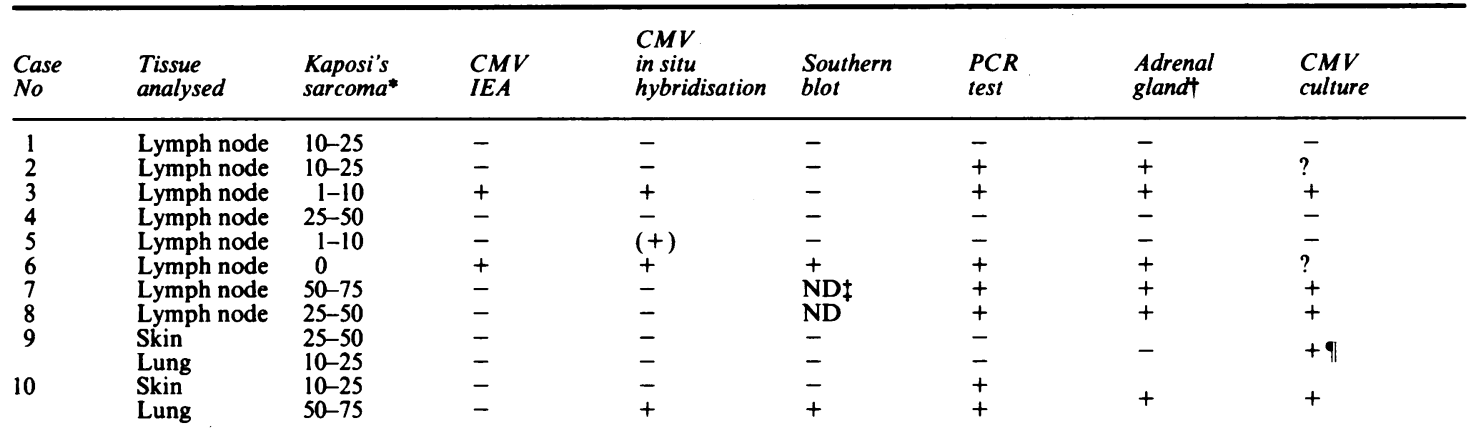

*Per cent Kaposi’s sarcoma nuclei in tissue sections analysed; †Inclusion bodies characteristic for CMV infection; ‡Not done because of low DNA yield.

CMV culture results were from samples of lungs, trachea, and adrenal glands obtained at necropsy, not from the tissues indicated. $\mid$ Only trachea positive. 
tubes (Greiner) and suspended in $1 \mathrm{ml} 100 \mathrm{mM}$ sodium chloride, $50 \mathrm{mM}$ Tris hydrochloric acid $(\mathrm{pH}$ $7 \cdot 5$ ), $5 \mathrm{mM}$ edetic acid, $1 \%$ sodium dodecyl sulphate containing $0.5 \mathrm{mg} / \mathrm{ml}$ proteinase $\mathrm{K}$ (Boehringer) and incubated at $37^{\circ} \mathrm{C}$ for one hour. The released DNA was purified by repeated phenol/chloroform extraction and alcohol precipitation, carried out as described previously. ${ }^{14}$

\section{SOUTHERN BLOT HYBRIDISATION}

Aliquots $(5 \mu \mathrm{g})$ of tissue DNA were digested with the restriction endonuclease EcoRI (Boehringer) according to the recommendations of the manufacturer and electrophoresed in duplicate in a $\mathbf{0 . 8 \%}$ agarose (Sigma type I) slabgel and transferred to nitrocellulose membranes (Schleicher and Schüll, type BA 84). Parallel blots were hybridised with 32P labelled cloned EcoRIJ fragment of CMV strain AD169 ${ }^{15}$ or with the pXE6.2 plasmid of herpes simplex virus type 2 (HSV-2) ${ }^{14}$ and autoradiographed as described previously. ${ }^{15}$

\section{POLYMERASE CHAIN REACTION (PCR)}

CMV specific primer and probe oligonucleotides for PCR manufactured using an applied biosystem 380A DNA synthesizer (Applied Biosystems, USA) were from the fourth exon of the CMV IEAl gene ${ }^{16}$ located in the $E c o R I J$ fragment of strain AD169. Primer A (5'AGC TGC ATG ATG TGA GCA AG-3') consisted of nucleotides 1767-1786 complementary to the antisense strand and primer B (5'-GAA GGC TGA GTT CTT GGT AA-3') was complementary to nucleotides 1894-1913 of the sense strand. PCR generates a 147 base pair fragment with these primers.

PCR was performed as described by Saiki and coworkers ${ }^{9}$ with some modifications. The reaction mixture contained $10 \mathrm{mM}$ Tris- $\mathrm{HCl}, \mathrm{pH} 9.6,10 \mathrm{mM}$ $\mathrm{MgCl}_{2}, 50 \mathrm{mM} \mathrm{NaCl}, 1 \mathrm{mM}$ each of deoxynucleotide triphosphate, $200 \mu \mathrm{g} / \mathrm{ml}$ bovine serum albumin, $0.5 \mu \mathrm{g}$ of primers A and B, $1 \mathrm{U}$ of Taq DNA polymerase (Perkin Elmer-Cetus, Emeryville, California) and $0.2 \mu \mathrm{g}$ DNA in a final volume of $50 \mu \mathrm{l}$ covered with $100 \mu \mathrm{l}$ paraffin oil to prevent evaporation. Thirty two incubation cycles of one minute at $95^{\circ} \mathrm{C}$ followed by three minutes at $65^{\circ} \mathrm{C}$ were performed with a laboratory robot arm (P\&P Elektronik $\mathrm{GmbH}$, Nürnberg, West Germany). Ten $\mu$ l of the amplification product was analysed by $2 \%$ agarose gel electrophoresis in the presence of ethidium bromide; the results were photographed under short wave ultraviolet illumination. As negative control human placenta DNA and DNAs from several other viruses (HSV types 1 and 2, human parovirus B19) were used. CMV DNA from strain AD169 was used as a positive control.
Results

The table shows the data on the detection of CMV in the different tissue sections. Immunohistochemical detection of CMV IEA was successful in the lymph node of case 3 in a few solitary cells outside the region with Kaposi's sarcoma and in the lymph node of case 6 in which no Kaposi's sarcoma was present. In situ hybridisation with biotinylated total CMV genome as probe detected solitary CMV infected cells in the lymph nodes of cases 3 and 6 and in the lung of case 10 . No morphologically normal cells with small inclusion bodies ${ }^{15}$ suggestive of early stages of infection or latent CMV genomes were found.

To be able to correlate Southern blot and PCR data directly with IEA and in situ hybridisation results on cryostat sections, tissue DNA was prepared from sequential sections from the same tissue blocks. Southern blot hybridisation was performed on EcoRI digested tissue DNAs using the CMV EcoRI J fragment as probe which detects a 10 kilobase CMV specific band. Control hybridisations were performed with the pXE6. 2 plasmid $^{14}$ containing a 9.5 kilobase insert which spans the HSV-2 BgIII N fragment. Only in case 10 (lung) and case 6 was a 10 kilobase band detected with the CMV probe; the results with the HSV-2 probe were negative in all patients analysed. PCR analysiso proved its potential by detecting a CMV specific $147 \mathrm{c}$ base pair band in the tissue DNAs of six patients (cases: $2,3,6,7,8$ and 10 -both lung and skin), the strongest signal was found in the lung of case 10 .

\section{Discussion}

Comparison of different CMV detection techniques (table) shows that with respect to sensitivity of detection histological examination of adrenal gland tissue and PCR analysis seem to be the methods of choice (six of 10 patients), closely followed by the infectious particle assay (five of 10); in two cases culture results were unreliable because of microbial contamination. Southern blotting seems to be the least sensitive (two of 10), although two potentially positive tissues could not be analysed because of low DNA yield; still it was the only technique which was negative in case 3 . In situ hybridisation with the total CMV genome as probe scored intermediate (four of 12); one case was dubious because of the presence of only one apparently positive cell while all other techniques in this patient (case 5) do not detect CMV. Although unlikely, this finding may be genuine because of sample variation in case of low numbers of infected cells. Although we used a larger biotinylated in situ hybridisation probe $(100 \%$ of the CMV genome compared with $17 \%$ ) than Grody and coworkers, ${ }^{7}$ we were unable to detect $\mathrm{CMV}$ in spindlelike Kaposi's sarcoma cells. ${ }^{7}$ 
Immunohistochemical IEA detection gave clear results in two of 12 tissues. Actually we considered in situ hybridisation and IEA detection to be of similar sensitivity because both techniques in our hands stained the same number of CMV positive cells in massively infected adrenal glands of patients with AIDS which we routinely use as positive controls (data not shown ${ }^{15}$ ). As a consequence of the detection system used, which also detects persistent endogenous peroxidase activity in some macrophages and granulocytes despite the inactivation step. Immunohistochemistry results on frozen sections must be interpreted extra carefully and proper control incubations should be included for each section.

The table shows that the results of CMV detection obtained with the different methods correlated very well. The only inconsistency seemed to be case 9 who had a positive CMV culture but was negative in all further analyses. This patient may have had an early stage of CMV infection in the trachea without spread to other organs. The apparent lower detection efficiency with in situ hybridisation and IEA compared with that of virus culture and PCR may reflect the fact that the latter techniques cover a much larger amount of (homogenised) tissue. This implies that the presence of only a small number of infected cells in each tissue block is easily missed in the few sections that are used for in situ hybridisation and IEA detection.

The conclusion that CMV infection seems unrelated to the development of Kaposi's sarcoma in patients with AIDS emerges from the results presented in the table. Because only hybridisation probes and PCR primers were used from the EcoRI $\mathrm{J}$ fragment of the CMV (AD169) genome, however, the presence of other parts of the CMV genome in the sarcoma celts would have been missed in the Southern blot and PCR experiments. The results of the in situ hybridisation experiments, which in our hands detect about 100 kilobase pairs of complementary DNA sequences per cell in model experiments (data not shown) and which used the complete CMV genome as probe, ${ }^{15}$ suggest that less than $50 \%$ of the CMV genome must have been present in each Kaposi's sarcoma cell. Moreover, the EcoRI $J$ fragment may contain part of the transforming gene(s) of CMV, ${ }^{17}$ which implies that the persistence of integrated copies of CMV-transforming genes in the sarcoma nuclei would have been detected by Southern blotting in cases where more than $10 \%$ of the cells were Kaposi's sarcoma cells (cases 1, 2, 4, 710). We cannot exclude the possibility that a small hitherto unidentified transforming fragment of CMV is responsible for the induction of Kaposi's sarcoma in some patients with AIDS. The fact remains, however, that Kaposi's sarcoma also occurs in patients without traces of CMV infection (table), which implies that there must be other aetiological factors in the pathogenesis of Kaposi's sarcoma.

This work was supported in part by the "Nier Stichting Nederland" Grant No. C-86606 and "Het Preventiefonds" Grant No. 28-1346.

\section{References}

1 Macher AM, Reichert CM, Strauss SE, et al. Death in AIDS patients: role of cytomegalovirus. N Engl J Med 1983;309: 1454-7.

2 Reichert CM, O'Leary TJ, Levens DL, Simrell CR, Macher AM. Autopsy pathology in the acquired immune deficiency syndrome. Am J Pathol 1984;112:357-82.

3 McNutt NS, Fletcher V, Conant MA. Early lesions of Kaposi's sarcoma in homosexual men. Am J Pathol 1983;111:62-77.

4 Drew WL, Miner RC, Ziegler JL, et al. Cytomegalovirus and Kaposi's sarcoma in young homosexual men. Lancet 1982;2:125-7.

5 Giraldo G, Beth E, Huang E-S. Kaposi's sarcoma and its relationship to cytomegalovirus (CMV) III. CMV DNA and CMV early antigens in Kaposi's sarcoma. Int $J$ Cancer 1980;26:23-9.

6 Delli Bovi P, Donti E, Knowles II DM, et al. Presence of chromosomal abnormalities and lack of AIDS retrovirus DNA sequences in AIDS-associated Kaposi's sarcoma. Cancer Res 1986;46:6333-8.

7 Grody WW, Lewin KJ, Naeim F. Detection of cytomegalovirus DNA in classic and epidemic Kaposi's sarcoma by in situ hybridization. Hum Pathol 1988;19:524-8.

8 Saiki RK, Scharf S, Faloona D, et al. Enzymatic amplification of $\beta$-globin genomic sequences and restriction site analysis for diagnosis of sickle cell anaemia. Science 1985;230:1350-4.

9 Saiki RK, Gelfland DH, Stoffel S, et al. Primer-directed enzymatic amplification of DNA with a thermostable DNA polymerase. Science 1988;239:487-91.

10 Shibata DK, Arnheim N, Martin WJ. Detection of human papilloma virus in paraffin embedded tissue using polymerase chain reaction. $J$ Exp Med 1988;167:225-30.

11 Jiwa NM, Zwaan FE, van Gemert GW, et al. Rapid detection of HCMV in blood of bone marrow transplant patients. Bone Marrow Transplant 1988;3(suppl 1):249-50.

12 Van den Berg FM, Tigges AJ, Schipper MEI, den Hartog-Jager FCA, Kroes WGM, Walboomers JMM. Expression of the nuclear oncogene p53 in colon tumours. $J$ Pathol 1988:56.

13 Graham RC, Lundholm U, Karnovsky RJ. Cytochemical demonstration of peroxidase activity with 3-amino-9-ethyl carbazole (letter to the editor). J Histochem Cytochem 1965;13:150-2.

14 Van den Berg FM, van Amstel PJ, Walboomers JMM. Construction of rat cell lines that contain potential morphologically transforming regions of the HSV-2 genome. Intervirology 1985;24:199-210.

15 Van den Berg FM, Jiwa M, Rook J, Geelen JLMC. Analysis and isolation of HCMV DNA by field inversion gel electrophoresis. J Gen Virol 1988;69:699-704.

16 Akrigg A, Willkinson GWG, Oram JD. The structure of the major immediate early gene of HCMV strain AD169. Virus Res 1985;2:107-21.

17 Nelson JA, Fleckenstein B, Galloway DA, McDougall JK. Transformation of NIH 3T3 cells with cloned fragments of human cytomegalovirus strain AD169. J Virol 1982;43:83-91.

Requests for reprints to: Dr F M van den Berg, Research Associate, Department of Pathology, Academic Medical Centre, University of Amsterdam, Merbergdreef 9, 1105 A2 Amsterdam, The Netherlands. 